\title{
Evaluation of Material Development and Presentation Process within the Scope of Instructional Technologies and Material Design Course
}

\author{
Şenel Elaldi ${ }^{1}$
}

\author{
Type/Tür: \\ Research/Araştırma \\ Received/Geliș Tarihi: October \\ 8/8 Ekim 2018 \\ Accepted/Kabul Tarihi: \\ December 25/ 25 Aralık 2018 \\ Page numbers/Sayfa No: $551-570$ \\ Corresponding \\ Author/İletişimden Sorumlu \\ Yazar: selaldi@cumhuriyet.edu.tr
}

\section{$\checkmark$ iThenticate}

This paper was checked for plagiarism using iThenticate during the preview process and before publication. / Bu çalışma ön inceleme sürecinde ve yayımlanmadan önce iThenticate yazılımı ile taranmıştır.

Copyright $@ 2018$ by Cumhuriyet University, Faculty of Education. All rights reserved.

\begin{abstract}
This study aimed to evaluate the development and presentation process of materials prepared by sophomores studying in the Department of Elementary Education in the Faculty of Education at Cumhuriyet University in the spring semester of 2017-2018 academic year within the scope of Instructional Technologies and Material Design course in accordance with the views of 52 sophomore preservice primary teachers (33 females, 19 males) taking this course in this term. An interview form including five semi structured questions and prepared by the researcher was used as a tool for the collection of data. The data were analyzed using Maxqda11, qualitative data analysis software, and descriptive analysis technique. After generating main categories and themes, codes obtained from the views were arranged according to the themes. The findings disclosed that sophomore preservice primary teachers had positive opinions about the development and presentation process of materials. However, regarding preparing a material and preparing a presentation themes, the participants also mentioned some difficulties they experienced during this process. At the end of the term, exhibition of the prepared materials by students was suggested for other teachers and students to visit and see them. Another suggestion includes sharing the materials prepared by the students within the scope of the ITMD course with nearby schools or village schools so that they make use of them in their teaching- learning process.
\end{abstract}

Keywords: Sophomore preservice primary teachers, material development, Instructional Technologies and Material Design course, lesson plan, Maxqda 11

\section{Suggested APA Citation/Önerilen APA Atıf Biçimi:}

Elaldı, Ş. (2018). Evaluation of material development and presentation process within the scope of instructional technologies and material design course. Cumhuriyet International Journal of Education, 7(4), 551-570. http://dx.doi.org/10.30703/cije.468442

\footnotetext{
1 Assoc. Prof.Dr., Cumhuriyet University, Education Faculty, Department of Primary Education, Pre-school Education, Sivas/Turkey

Doçent Dr., Cumhuriyet Üniversitesi, Eğitim Fakültesi, Temel Eğitim Bölümü/Okul Öncesi Eğitimi Anabilim

Dalı, Sivas/Türkiye

e-mail: selaldi@cumhuriyet.edu.tr

ORCID ID: https: / / orcid.org/0000-0003-0780-4207
} 


\title{
Öğretim Teknolojileri ve Materyal Tasarımı Dersi Kapsamında Materyal Geliştirme ve Sunum Sürecinin Değerlendirilmesi
}

\begin{abstract}
Öz
Bu çalışma Cumhuriyet Üniversitesi Eğitim Fakültesi Sınıf Öğretmenliği Anabilim Dalında 2017-2018 yılı bahar yarı döneminde öğrenimlerini sürdüren 2. Sınıf öğrencilerinin Öğretim Teknolojileri ve Materyal Tasarımı dersi kapsamında hazırladıkları materyalleri geliştirme ve sunum sürecinin bu dersi alan 52 ikinci sınıf öğretmen adayının (33 kız, 19 erkek) görüşleri doğrultusunda değerlendirilmesini kapsamaktadır. Veriler, araştırmacı tarafından araştırmanın amacına göre hazırlanmış beş yarı yapılandırılmış sorudan oluşan bir görüşme formu ile toplanmıştır. Veriler Maxqda 11 nitel veri analizi programı ve betimsel analiz tekniği ile analiz edilmiştir. Ana kategoriler ve temalar oluşturulduktan sonra, görüşlerden elde edilen kodlar temalar altında sıralanmıştır. Bulgular, ikinci sınıf öğretmen adaylarının, materyallerin geliştirilmesi ve sunum süreci hakkında olumlu düşüncelere sahip olduğunu ortaya koymuştur. Ancak, materyal hazırlama ve sunum aşamalarına yönelik yaşanılan zorluklar da ortaya çıkmıştır. Dönem sonunda, öğrenciler tarafından hazırlanan materyallerin diğer öğretmenler ve öğrenciler tarafından ziyaret edilerek görülmesi açısından sergilenmesi önerilmektedir. Diğer bir öneride bu materyallerin yakınlardaki okullar veya köy okulları ile paylaşılarak öğrenme- öğretme sürecinde kullanılmasını içermektedir.
\end{abstract}

Anahtar Kelimeler: Sınıf öğretmenliği ikinci sınıf öğretmen adayları, materyal geliştirme, öğretim teknolojileri ve materyal tasarımı dersi, ders planı, Maxqda 11

\section{Introduction}

Teacher centered education following a coursebook has formed the basis of long- time teaching in education. However, today, modern multi-media learning opportunities are created thanks to technological facilities, many resources or materials besides teachers and textbooks. Therefore, there is a tendency of teachers to cater to various technology based teaching styles in their classrooms. Especially the contribution of computer-based technologies to the preparation of teaching materials, presentation and evaluation process has become widespread. Nowadays, all kinds of teaching materials, equipment and technology used especially visually and audibly in education are considered to be important components of teaching learning environments and have of course major contributions, such as addressing the entire sensory organs, providing real life experiences, meeting the individual needs of students, taking attention, facilitating remembering, saving time, embodying abstract concepts, making learning permanent, providing safe observation (Akçay, Tüysüz, Feyzioğlu, \& Oğuz, 2008; Heinich, Molenda, Russell, \& Smaldino, 2002). Furthermore, today's students as consumers of technology are very much comfortable thanks to outstanding communication ability of the Internet. They show a substantial increase in using several technological dimensions to improve their academic performances (Metzger, Flanagin, \& Zwarun, 2003). Therefore, due to remarkably common availability of online lecture and homework programs, digital access to course materials, the 'classroom' is not just a physical space anymore (Oblinger, 2005).

On the other hand, the Constructivist Curriculum Reform put into implementation in Turkey in 2004 - 2005 academic year has substantially changed the philosophy of education (Inal, 2005) due to being a transition from knowledge to technology in the contemporary world. This renewed curriculum with a constructivist 
approach that supports student-centered education and enables students to be more active in the learning process replaced the former behaviorist approach which had been exposed to criticism for being teacher-centered and not being compatible with technological developments (Ministry of National Education [MoNE], 2004, 227228).With the constructivist approach, new concepts such as student-centered approach, inquiry-based learning, learning to learn, guidance of teachers, multiple intelligence approach and active learning have been introduced into the educational system (Li, 2012). Due to being done extensive amendments especially in the primary school curriculum and started nationwide implementation since 2005-2006 academic year in Turkey, it is important that both teachers and preservice students are ensured to adapt to the contemporary education's needs. Therefore, teachers are now moving more towards learner-centered instructional strategies as motivated by Turkish curriculum reforms. In order to accommodate these instructional strategies and to fulfill demanding needs of students, teachers should support latest instructional strategies and practices enthusiastically (Georgiana \& Hosford, 2009).

However, technology alone does not boost teaching; successful integration of technology into teaching is possible with teachers to use technological facilities effectively and efficiently. Therefore, teachers are required to be fully equipped with technological competencies in pre-service training (Zhou, Zhao, $\mathrm{Hu}$, Liu, \& Xing, 2010). In this context, courses aimed at bringing these competencies to preservice teachers in terms of adaptation and use of technology and innovations are already included in teacher training programs.

Instructional Technologies and Material Design (ITMD) course is one of the courses specified to be taught in Teacher Training Undergraduate Programs by the Council of Higher Education (YÖK). Within the framework of the National Education Development Project carried out in cooperation with the YÖK and World Bank in 1998, the ITMD course was added as a compulsory course to all teacher training programs (YÖK, 1998). The course has four credits, two hours theoretical and two hours practical. Before taking this course, the necessary technology knowledge is provided by the courses of Computer I and Computer II to preservice teachers. Within the scope of the ITMD course, the characteristics of various instructional technologies, their place and use in the teaching process, the development of instructional materials are given to preservice teachers. Through this course, it is aimed to introduce various teaching technologies to students, to guide them in arranging the appropriate environment, and on the other hand, to help them develop teaching materials with existing possibilities when they are teachers. In this vein, Heinich, Molenda, Russell, \& Smaldino, (2002) indicated that expected contributions of instructional materials to teaching - learning processes depend on their correct and appropriate designs. Within the course, preservice teachers prepare various materials, share their material development process with their friends and they also have the opportunity to see other material samples along with their own materials.

This study is significant for making material development process more effective for students studying in the Faculty of Education. In this regard, the aim of this study is to evaluate the development and presentation process of materials prepared by sophomores within the scope of the ITMD course. This process consists of students' choosing a topic taking place in the guide books of primary education 
from 1st to 4th grade, presentation of the lesson plans prepared for the selected topic, presenting appropriate course presentation using the appropriate slide techniques at the student level and in line with the lesson plan they have chosen and introducing the materials that they prepared to use in the course.

The following questions have been included in the study to find out the views of sophomores on this course:

1. What elements should be considered when choosing a topic?

2. What elements should be considered when preparing a lesson plan?

3. What elements should be considered when preparing a material?

4. What elements should be considered when giving a presentation related to the topic?

5. What are the contributions of activities carried out during the ITMD course to the process?

\section{Method}

This study included a case study research method, as a type of qualitative research design. A case study is used in the analysis and description of, for example each person individually, a group of people, a process, an event, a problem or various problems, etc. in detail (Sagadin, 1991, as cited in Starman, 2013) and includes coding and categorization outcomes formulated by detailed reading (Merriam, 1998). In this context, in order to get a lot of detail about material development and presentation process from a group of students, this method was used in the current study.

\section{Participants}

Participants of the study included 52 sophomore preservice primary teachers (33 females, 19 males) who take ITMD course in the Faculty of Education at Cumhuriyet University, Sivas, Turkey in the in the spring semester of 2017-2018 academic year.

\section{Data Collection}

A semi-structured interview technique, one of the qualitative data collection methods, was applied to collect the research data. An interview form including open-ended questions was developed by the researcher in view of expert opinions and literature review. Questions in the form were generated to determine the sophomores' views on the process within the scope of the ITMD course. In analyzing the text data, Qualitative Data Analysis Software, Maxqda 11 program was used. Maxqda, as a text search tool, enables researches automated searches to look for occurrences of codes or themes and reveals relationships between codes (D'Andrea, Waters \& Rudd, 2011). A pilot study with 2 participants who are as similar as possible to the target population was performed in order to improve the internal validity of interview questions. Both the pilot participants were asked to provide feedback in order to identify ambiguities and difficult questions. Then, unnecessary, ambiguous or difficult questions were discarded and some adjustments were made on the interview questions. Moreover, to ensure the reliability and validity of the qualitative data, volunteers were included and direct quotations of the participants were integrated into the study. On the other hand, interrater reliability was tested by Cohen's kappa statistical measure (Cohen, 1960) to reveal the agreement of two raters for each theme which was calculated separately and given in Table 6 (see Appendix). Cohen's kappa coefficient for each theme was 
calculated as .549 for choosing a topic, .761 for preparing a lesson plan, .849 for preparing a material, .807 for preparing a presentation and, .860 for applying in the ITMD course. The results were between moderate agreement and near perfect agreement according to Kappa results suggested by Cohen (1960) as Kappa $=0.41$ to 0.60 moderate agreement and Kappa $=0.81$ to 1.00 near perfect agreement.

Interviews were conducted between March 2018 and June 2018. Besides faceto-face interviews lasting at least 30 minutes, interviewing by telephone was used for two participants who were not easy to access on weekdays after the ITMD course. On the other hand, with the permission of the interviewees, interviews were tape recorded and respondents were guaranteed complete confidentiality.

\section{Data Analysis}

Data obtained with the semi-structured interviews were analyzed and interpreted in accordance with the descriptive analysis technique. In the data analysis process, after coding each participant's responses as P2-M/F (P:Participant; 2:Participant No; M:Male/F:Female), all the interview data were transcribed verbatim. Accuracy of the transcripts were reviewed and then data were analyzed using Maxqda 11 program and descriptive analysis technique. Collected data, in descriptive analysis, are summarized and interpreted in the light of pre-defined themes (Yıldırım \& Şimşek, 2008). The qualitative data analysis process involved four steps (Tutty, Rothery, \& Grinnell, 1996) which were (1) data coding which included recognizing and encoding the information to identify and develop themes from them (Boyatzis, 1998), (2) themes' identification via careful reading and re-reading of the data (Rice \& Ezzy, 1999), (3) Regulation of codes and themes (4) Illustrating the codes and themes with a diagram (Miles \& Huberman, 1994).

\section{Findings}

According to the analysis results, two main categories as "Development Process" and "Presentation and Contribution Process" were generated. While three themes, namely, "Elements to be considered when choosing a topic", "Elements to be considered when preparing a lesson plan", "Elements to be considered when preparing a material" took place under the Development Process category, two themes, namely, "Elements to be considered when giving a presentation related to the topic" and "Contributions of activities carried out during the ITMD course to the process" were included in the Presentation and Contribution Process category. These themes and related codes were illustrated in Figure 1 and Figure 2. 


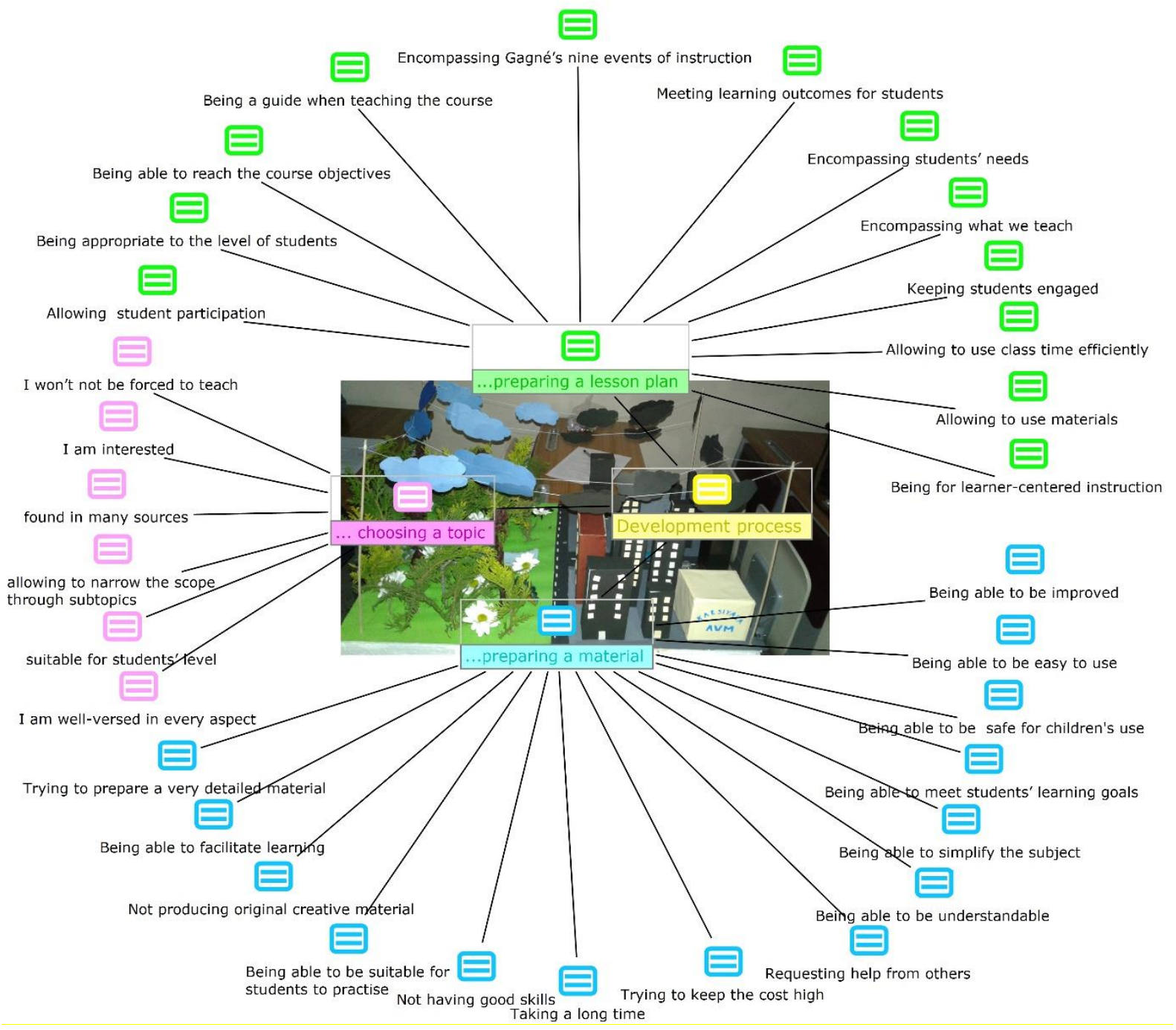

Figure 1. Themes and Codes Related to Development Process

\section{Elements to be Considered When Choosing a Topic}

Views of the participants related to the first theme, namely, elements to be considered when choosing a topic and the related codes and their frequencies were given in Table 1 .

\section{Table 1}

Views of the Participants Regarding Elements to be Considered When Choosing a Topic

\begin{tabular}{lc}
\hline Views & $f$ \\
\hline A topic that I will not have difficulty in designing the material & 41 \\
A topic I am interested in & 36 \\
A topic that is suitable for students' level & 25 \\
A topic that is not difficult to teach & 9 \\
A topic that I am well-versed in every aspect & 6 \\
A topic that can be found in many sources & 1 \\
A topic that will allow me to narrow the scope through subtopics & 1 \\
Total & 119 \\
\hline
\end{tabular}


As given in Table 1, the most frequently reported code was related to the topic that will not cause difficulties in designing the related material. In this context, a participant (P15/F) stated, "It is important to choose a topic relevant to the material to be designed beforehand". Accordingly, another participant (P51/F) wanted to emphasize that because material development is an ongoing process, it begins with choosing the relevant topic which does not put me into trouble in this process. The participant P17/M stressed the importance of choosing a topic relevant to the material to be designed as "If I'm obliged to choose a topic that does not interest me or I know little about it, it is unlikely to ensure that I can develop a material which is suitable for my goal". In this regard, Barnard and Zemach (2003) claim that those engaged in creating or adapting materials will be required to become familiar with the topic and learning materials available in their specialist subject area. Some views of the participants were associated with topic selection and its teaching. For example, a participant (P9/F) asserted "I prefer selecting a topic that I have already had some knowledge about it or a topic that interests me the most in order to avoid being in a difficult situation in front of others when teaching it."

For some participants (i.e., P45/F, P11/M, P49/F and P23/M), choosing an appropriate topic is an important requirement for generating a large number of ideas, commonly in relation to a specific purpose. For them, a well-chosen topic is key to the success of good teaching and academic success. In this context, P11/M stated "A good way to be able to teach a subject at students' level is to find out as much as I can about my topic beforehand and to negotiate it with my friends in order to be able to see it from a different angle. In addition, the participant (P50/F) stressed that I do not expect to speak fluently on a subject that I know little or nothing about. Therefore, picking an area where I have expert knowledge and I am well-versed in every aspect increases the likelihood that I will effectively communicate with students. On the other hand one participant $(\mathrm{P} 13 / \mathrm{F})$ emphasized that in order to give more detailed information in a shorter amount of time, I need to narrow the scope of my general topic by breaking it into the important parts that will increase the likelihood of more effective and full presentation.

\section{Elements to be Considered When Preparing a Lesson Plan}

Views of the participants regarding elements to be taken into consideration when preparing a lesson plan were given in Table 2. It indicates that almost all the participants have shared the idea that an effective lesson plan guides teachers and students in a learning environment and enables students to efficiently meet their goals. For some participants (i.e., P32/M, P15/F, P48/M and P9/F), when planning learnercentered instruction, Gagné Style offers students a lot of opportunities to engage them in the lesson and make them interested in what they are learning. For them, "Within the scope of Gagné's nine events of instruction, teachers are intended to guide their students and set them up for success so students are able to learn how to find solutions and demonstrate the learning outcomes using the skills that they have learned". In this context, P32/M added that because Gagné's nine-step lesson delivery makes use of the ability of students to assimilate information, teachers need to create a lesson plan that includes an instructional design prepared according to Gagné's nine events of instruction. By the same token, P2/F stated "For me, division of the standard lesson 
plan into separate units seems beneficial to instructors who are better understanding the dynamics of teaching and learning."

Table2

Views of the Participants Regarding Elements to be Considered When Preparing a Lesson Plan

\begin{tabular}{ll}
\hline Views & $f$ \\
\hline Being a guide when teaching the course & 48 \\
Encompassing what we teach & 47 \\
Encompassing students' needs & 43 \\
Encompassing Gagné's nine events of instruction & 40 \\
Being appropriate to the level of students & 31 \\
Being for learner-centered instruction & 22 \\
Being able to reach the course objectives & 19 \\
Allowing to use class time efficiently & 8 \\
Allowing to use materials & 5 \\
Allowing student participation & 3 \\
Meeting learning outcomes for students & 2 \\
Keeping students engaged & 2 \\
Total & 270 \\
\hline
\end{tabular}

On the other hand, some participants (P5/F and P19/M) stressed "Lesson planning is about meeting learning outcomes for students; therefore, it needs to focus on what students need to demonstrate at the end of the lesson." Moreover, the participant P26/F expressed "Lesson planning is required for us because it enables us to keep track of our lesson delivery". Another participant (P13/F) stated that for an effective lesson plan, it is necessary to focus on students' needs and she added, "I know that I can plan my best lessons when I try to put myself in my students' shoes." Similarly, the participant P6/F remarked that certainly the best lesson plan is the one that works for the students. The participant P33/M remarked "The objective of the lesson for me is not to deliver content, but to engage students in the lesson and make them interested in what they are learning." And he added "Planning a lesson requires more than rote teaching and learning." Some participants (i.e. P16/F, P28/F and P19/M) mentioned about the importance of using materials within the scope of a lesson plan. For them, in helping students to take charge of their learning, teachers should plan and develop meaningful instructional materials that are involved in a lesson plan. In this regard, the participant P4/F noted "I try to create a good lesson design beginning with a review of previously learned materials and introducing new materials which will ensure opportunities for students to practice." Regarding time management in a lesson plan, the participant (P19/M) stated "the amount of time that will be allotted for each stage of a lesson plan should definitely take place in planning phase. He continues "if I adjust managing time, my students will not need to glance at the clock and time will fly for them when they are learning with fun."

\section{Elements to be Considered When Preparing a Material}

This theme included a subtheme which was "Problems / difficulties experienced when preparing a material". Views of the participants regarding elements to be considered when preparing a material and problems / difficulties experienced were given in Table 3. 
Table3

Views of the Participants Regarding Elements to be Considered When Preparing a Material and Problems /Difficulties Experienced

\begin{tabular}{ll}
\hline Views & $f$ \\
\hline Being able to be easy to use & 39 \\
Being able to facilitate learning & 27 \\
Being able to be understandable & 22 \\
Being able to be suitable for students to practise & 15 \\
Being able to simplify the subject & 11 \\
Being able to be safe for children's use & 10 \\
Being able to meet students' learning goals & 8 \\
Being able to be improved & 2 \\
Total & 134 \\
\hline Views regarding the subtheme “Problems /difficulties experienced" & 14 \\
\hline Trying to prepare a very detailed material with a wish of getting high marks & 7 \\
Not having good skills & 3 \\
Taking a long time & 2 \\
Not producing original creative material & 2 \\
Requesting help from others & 2 \\
Trying to keep the cost high & 30 \\
\hline
\end{tabular}

As shown in Table 3, the participants' views promotes that preparing materials helps students maximize their learning potential. Some participants (i.e. P23/M, P35/F, P49/F, and P51/F) stated that instructional materials should facilitate learning by simplifying the subject. The participant (P8/M) explained "Depending on the type of the lesson being taught I try to use teaching learning materials or aids in order to support teaching learning situation. For example, it may be better to use audio-visual materials in the classroom". Another participant $(\mathrm{P} 2 / \mathrm{F})$ stated that materials to support the class should be based on objectives of education and evaluation procedures and continued "Any material can be used if it is good selected for facilitating learning." In addition, due to the fact that the use of materials increases basic knowledge and provides students with opportunities to use it easily in order to build new knowledge on this background, some participants (i.e. P7/F, P21/M, P30/M asserted that one's understanding of materials depends to a great degree on how much s/he has already known about the subject. For example, the participant (P7/F) stated "The more you understand the materials that you have chosen from, the better choices you will make". Regarding the ease of use of the material, the participant (P37/F) pointed out "I prefer selecting materials easy to use for me and my students. Although as a general rule, materials should be slightly higher in students' level of difficulty than their current level, it is possible to say that sometimes using complicated materials may result problems in terms of accessing knowledge with much difficulty." A participant (P53/F) claimed that there is a common misconception among novice teachers and some experienced teachers that it may be appropriate to include more materials in their teaching. However, since students have a limited ability to learn, it is better to keep the quantity of material within that limit. Picking the most important stuff, and making it good is better than using much more materials. In this vein, the 
participant (P8/M) said "If I began teaching, I would get rid of unimportant materials so they do not distract students from the important information."

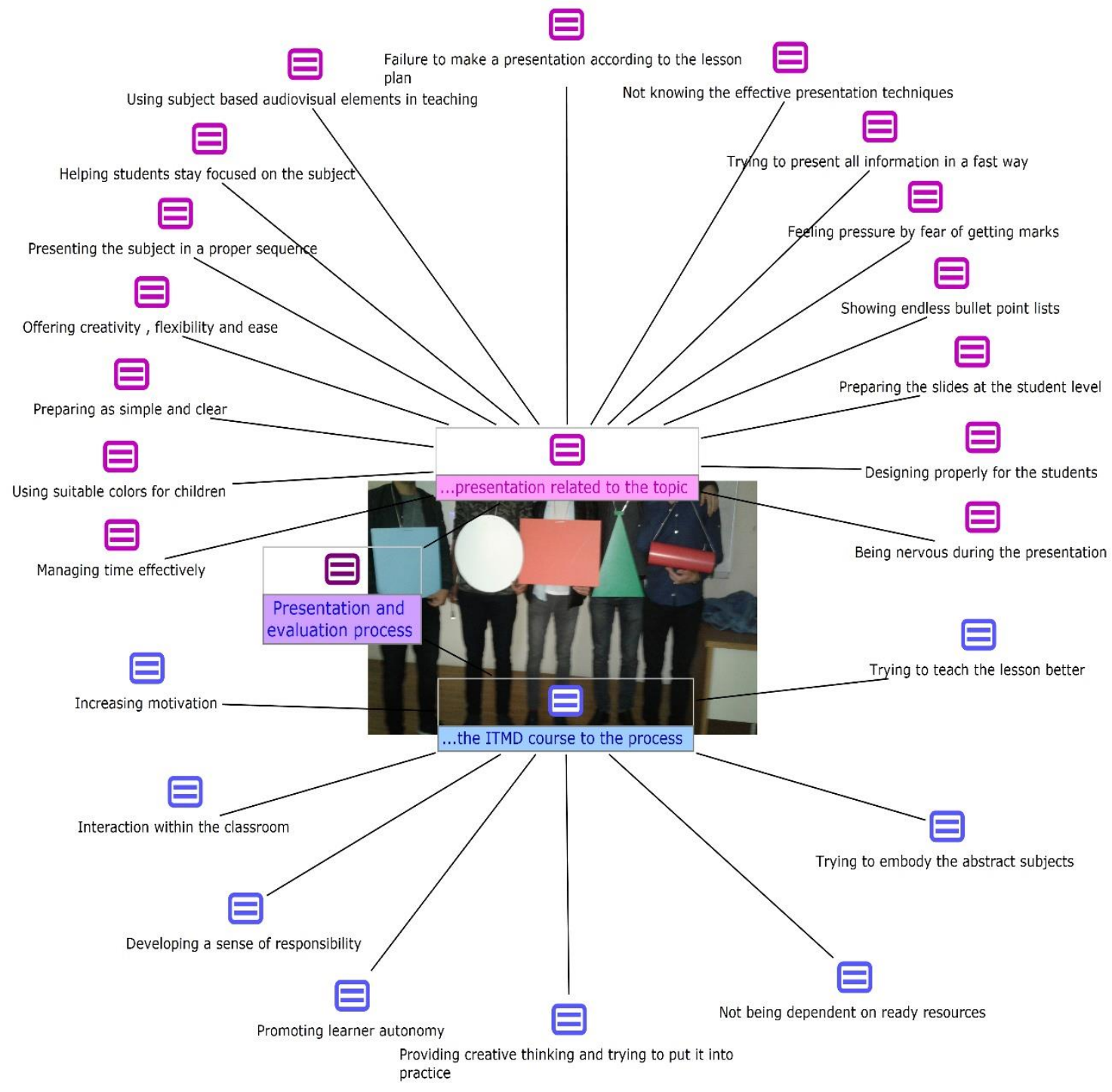

Figure 2. Themes and codes related to the presentation and contribution process

Regarding the subtheme "Problems / difficulties experienced", a participant $(\mathrm{P} 42 / \mathrm{M})$ remarked "Most of my friends in my class and me see material preparation as a means of getting marks. Because we would like to get higher marks, we try to prepare very detailed and high cost of materials." According to the participant P50/F, some students are not skilled at preparing materials. Therefore, they have to request help from their peers or from other people who prepare materials with money. On the other hand, some views were relatively related to limited time that is devoted to create a material. For example, the participant P13/F stated "Since I had to concentrate on my other lessons especially during the exam time, I could not spend much time to create an instructional material." Another participant (P38/F) said "Although I knew I would get a mark from the material I prepared, I couldn't do my best due to limited time stemming from other tasks my other teachers wanted me to perform." 


\section{Elements to be Considered When Giving a Presentation Related to the Topic}

Another theme was related to the elements to be considered when giving a presentation related to the topic and the sub-theme problems / difficulties experienced. The related codes and frequencies were given in Table 4.

Table 4

Views of the Participants Regarding Elements to be Considered When Giving a Presentation Related to the Topic and Problems /Difficulties Experienced

\begin{tabular}{ll}
\hline Views & $f$ \\
\hline Using audiovisual elements in teaching related to the subject & 42 \\
Preparing the slides at the student level & 39 \\
Designing properly for the students & 31 \\
Preparing as simple and clear & 24 \\
Helping students stay focused on the subject & 12 \\
Managing time effectively & 5 \\
Presenting the subject in a proper sequence & 2 \\
Offering creativity, flexibility and ease & 1 \\
Using suitable colors for children & 1 \\
Total & 157 \\
\hline \multicolumn{2}{c}{ Views regarding the subtheme "Problems /difficulties experienced" } \\
\hline Not knowing the effective presentation techniques & 21 \\
Being nervous during the presentation & 17 \\
Feeling pressure by fear of getting marks & 13 \\
Showing endless bullet point lists & 10 \\
Trying to present all information in a fast way & 8 \\
Failure to make a presentation in the direction of the lesson plan prepared in advance & 4 \\
Total & 73 \\
\hline
\end{tabular}

As given in Table 4, the most frequently reported code was related to using PowerPoint presentations as audiovisual aids. In this sense, the participant P37/F stated "When preparing my presentation, I give importance to a nice appearance and interesting graphics in order to keep students interested." Some participants (i.e., P16/F, P21/M and P48/M) highlighted that an effective presentation should include visual representations, video links, graphics, animations, cartoons, tables and so forth. It should also encourage students' engagement and enhance their memories of the key points." Another participant (P12/M) said that through using PowerPoints in classes, a teacher can enhance some another sense and he added "I believe in using presentations for different senses: auditive, visual, feeling, moving, and acting." The importance of using audiovisual elements in learning also stressed by the participant P15/F as "I think PowerPoint can help move from just listening to also seeing. All are needed in learning." A participant P43/F focused on using pictures in a presentation and she added "Creating presentations that include pictures to reinforce the content is important to encourage students to critically think about the content presented." For some participants (i.e., P20/F, P34/M and P43/F), if prepared properly at the level of students, PowerPoint presentations can help a teacher transfer key points. For them, it is to say that the effectiveness of PowerPoints depends on how they are used, how much experience the user has, and how much effort they are able/willing to put in. They also pointed out that the utility of PowerPoint in the classroom depends on teachers' planning skills and time management. Besides, at the end of the presentation, 
a short quiz can help teachers see if the intended outcomes have been achieved or not. Some codes emerged related to managing time effectively. The participant P2/F stressed "Via using PowerPoints, a teacher can discuss about main topics in the limit time". According to the participant P14/F, because teachers have little time to think about their teaching and how best to communicate their subject matter, under pressure of time, bullet point slides make presentation easier. Related to the emerging code "Presenting the subject in a proper sequence", a participant (P23/M) expressed " PowerPoint is a tool for me to help organize my presentation in a proper sequence so that I will not forget any points that I should give in proper sequence. My topic I have chosen requires a lot of complex illustrations and diagrams that it is impossible to draw them properly on the board. So it helps present the material clearly, coherently and in logical sequence. That's why PowerPoint is a great help if it is properly utilized." On the other hand, a participant (P30/M) commented on the usefulness of PowerPoint presentation. He said "When preparing a PowerPoint presentation, it offers creativity, flexibility and ease. Since PowerPoint offers a variety of predefined templates and layouts for us, we can edit the information in slides finished, delete unnecessary slides, add slides forgotten and rearrange the order of slides in the presentation."

Regarding the subtheme "Problems / difficulties experienced", the highest frequency belonged to the code "Not knowing the effective presentation techniques". In this context, the participant P45/F claimed "I find it difficult to prepare an effective presentation due to my little computer experience and knowledge." Another participant (P14/F) said "Most of my friends show endless bullet point lists or overloaded information on each slide rather than using it as a visual aid and they simply read their PowerPoints to us in the class." In this vein, a participant (P10/M) explained the results they have encountered when preparing their presentations as " $I$ think it is simply a lack of effort and lack of preparation time undoubtedly contributes to the emergence of poor results in our presentations. As students, we have generally high course loads and, therefore, an effective preparation of PowerPoints is often secondary to us." The participant P52/F mentioned about her nervousness and not bringing it under control. She added "Although PowerPoint presentations give us a chance to build self-esteem, giving a presentation in front of others is always stressful. I cannot decrease my level of nervousness." It is understood from the views of the participants that PowerPoint is an additional tool - not the prime teaching tool. The prime teaching tool should always be the teacher.

\section{Contributions of Activities Carried Out During the ITMD Course to the Process}

Views of the participants regarding contributions of activities carried out during the ITMD course to the process were given in Table 5. The views of the participants regarding contributions of activities carried out during the ITMD course revealed that they gained positive experience from this course. For example, the participant P14/F remarked "Our job is to move all students forward. In this vein, through this course, I try to learn what and how to do in the classroom, as a teacher candidate, especially, in the preparation of proper material and implementation of it in order to boost my students' self-confidence to learn." Regarding the most frequently reported code "Boosting self-confidence", a participant (P22/M) pointed out "In my experience from this course, I think, it is very profitable to teach students topics through materials and 
presentations that lead to increase in their self-confidence." Another participant (P44/M) said "I believe that confidence will increase as students have more opportunities to get involved in the lesson."

Table 5

Views of the Participants Regarding Contributions of Activities Carried Out During the ITMD Course to the Process

\begin{tabular}{ll}
\hline Views & $f$ \\
\hline Boosting self-confidence & 42 \\
Increasing motivation & 40 \\
Trying to teach the lesson better & 36 \\
Trying to embody the abstract subjects & 13 \\
Interaction within the classroom & 11 \\
Developing a sense of responsibility & 7 \\
Providing creative thinking and trying to put it into practice & 1 \\
Not being dependent on ready resources & 1 \\
Promoting learner autonomy & 1 \\
Total & 152 \\
\hline
\end{tabular}

One of the participants (P39/F) stressed on the classroom environment and its impact on gaining self- confidence. She continued "I would say that classroom climate is very important to encourage timid students to engage in the lesson and increase in their self-confidence. Namely, a non- threatening climate is a confidence booster. Therefore, what we need is to make a warm atmosphere in classroom so that students interact to each other without hesitation. Personally for me, group study in the ITMD course made us closer. The closer the students are as a group the less intimidated they would feel". The participant P27/M concluded "I have observed detectable improvement in my confidence thanks to the ITMD course." Regarding the code "Increasing motivation", a participant (P39/F) expressed that the most essential one to increase motivation, at least to me, is teachers' awareness of learners' wants. And she added "In the ITMD course I believe that as learners our personal expectations about the course were met through a sincere collaboration between us and our teacher; because the natural presence of a logical collaboration between teachers and learners can indubitably lead to learner motivation and learner autonomy in the long run." On the other hand, it was understood from the views that selection of the subject by students in the ITMD course led to the enhancement of motivation. For example, the participant P46/F reported "What has worked best for myself and for my friends in the ITMD course was that our teacher let us learn by working on projects we chose ourselves within the general thematic scope of the course, and encouraged us to select a topic we were enthusiastic about, that related to our interests and experiences." In a similar manner, the participant P19/M uttered "I think the best side of this course was that we were allowed to choose the topic we were most interested in and the end of our presentations, we got positive feedback." Regarding the encouraging effect of other students' presentations on increasing motivation, the participant P10/M pointed out "The presentation of other students motivated and encouraged me to do more and share in the class." In this regard, the participant P37/F remarked "Presenting my work in front of my classmates made me feel proud." Related to the code "Promoting 
learner autonomy", the participant P36/M stressed "In the ITMD course, we first learned theoretical concepts, reflected on them, talked about them, then put them into practice with presentations. This framework allowed us to own our educational experience autonomously, while being accountable to a group's critique." Another participant (P51/F) uttered "In view point I experienced that the ITMD course provided me to take charge of my own learning." The participant (P38/F) explained her feelings as "Our teacher never tried us to bombard with numerous tasks; she let us have our own point of view and take some freedom to prepare and present our work." In addition, a participant (P16/F) explained "The information that I gained on this course is immeasurable. The experience provided me with knowledge of different materials and their use. I learned the contents of this course. I do not feel as though all of this knowledge could be gained sitting in a classroom. The importance of interaction in the classroom should not be forgotten."

\section{Discussion}

This study aimed to evaluate the development and presentation process of materials prepared by sophomores ( $\mathrm{N}=52 ; 33$ females, 19 males) within the scope of ITMD course. In accordance with this purpose, the process was discussed in four stages, namely, students' choosing a topic taking place in the guide books of primary education from 1st to 4th grade, presentation of the lesson plans prepared for the selected topic, presenting appropriate course presentation using the appropriate slide techniques at the student level and in line with the lesson plan they have chosen and introducing the materials that they prepared to use in the course. Based on these stages, two categories as "Development Process" and "Presentation and Contribution Process" and five themes under these categories as "Elements to be considered when choosing a topic", "Elements to be considered when preparing a lesson plan", "Elements to be considered when preparing a material", "Elements to be considered when giving a presentation related to the topic " and "Contributions of activities carried out during the ITMD course to the process" were generated.

Regarding the first theme "Elements to be considered when choosing a topic", the study revealed that the participants gave importance to choose a topic relevant to the material to be designed beforehand or a topic that interests them the most or a topic they have already had some knowledge about it in order to avoid being in a difficult situation in front of others when teaching it. Since being interested in a topic enhances learning, and then leads to better performance and achievement (Hidi, 1990), individuals learn more about a topic that they exhibit a positive attitude and personal value and they become more skilled and knowledgeable (Hidi \& Renninger, 2006). On the other hand, preferring activities and topics that we find interesting serve an important function in our lives by keeping away the feeling of unease and discontent (Sheldon \& Elliot, 1999). Hence, interest in a topic or activity can have a significant effect on students' learning enthusiastically.

The views in accordance with the theme "Elements to be considered when preparing a lesson plan" disclosed that an effective lesson plan guides teachers and students in a learning environment and enables students to efficiently meet their goals. A similar view which is supported by Pang's (2019) study is that lesson planning gives concrete support which pre-service teachers need in their initial phase of developing 
instructional competence. Moreover, the participants remarked that they found division of the standard lesson plan into separate units according to Gagnés nine events of instruction beneficial for both instructors who are better understanding the dynamics of teaching and learning and students who use their ability for assimilating information. According to Khadjooi, Rostami and Ishaq (2011), as Gagné's nine-step model is necessary for giving a holistic view to the teaching and the structure of lesson plan. Applying this model is an excellent way to certify an efficient and systematic learning program. The participants also put emphasis on managing time efficiently during a course. This is because teacher candidates' time allocation of in-class activities and time commitment on teaching-related activities will help gain a good understanding about preparing themselves for their future career (Link, Swann, \& Bozeman, 2008)

Related to the theme "Elements to be considered when preparing a material", the participants supported the idea that the use of materials increases basic knowledge and therefore, any material can be used if it is selected well for facilitating learning. Similarly, Yalın (2002) remarked that instructional materials have an important place to make the learning permanent, to attract students' interest, to improve learning, to manage time, to make a stimulating effect on learning, to ensure the continuity of thoughts, to strengthen teaching process and, to contribute to the development of words. In this context, the participants taking place in this study stated that they gave importance to focus on these main points when preparing their materials. On the other hand, some views led to generate the subtheme "Problems / difficulties experienced" during material preparation process. The most frequently occurring code was related to attempt to prepare a very detailed material with a wish of getting high marks. If students are encouraged to prepare complex or expensive materials in order that they obtain as high marks as possible without being explicitly told what to do, it seems possible to be experienced such kind of problems. In addition, other problems posed by the participants were difficulty in allocating too much time to prepare materials due to being obliged to allow time for the tasks given by their other teachers and preparing materials with higher costs. However, as Hamza (2012) has stated throughout the design and development process of material, it's important to remember that avoiding any lengthy and costly time consuming materials is paramount. On the other hand, the participants' views revealed that it was a bit troublesome to search and find out proper materials or to prepare them in an easy manner due to not being well trained. Similarly, Lazar (2017) pointed out that because of some reasons stemming from instructors or educational institutions, the use of instructional materials has some limitations. For example, some instructors are not well trained both to understand the effectiveness and importance of the materials and to make use of them in accordance with essential teaching objectives. Some educational institutions do not have the appropriate equipment and environment to apply it.

Regarding the theme "Elements to be considered when giving a presentation related to the topic", the most prominent code was giving importance to audiovisual aids. Previous research yielded the similar results (i.e. Demirel, Seferoğlu \& Yağc1, 2004; Lazar, 2017; Moreno \& Mayer, 2002; Rasul, Bukhsh \& Batoolc, 2011; Yaşar, 2004). According to Demirel et al. (2004) and Rasul et al. (2011), the learning environment created by audiovisual aids makes teaching effective and enables the best 
dissemination of knowledge. On the other hand, the codes including properly designed PowerPoint presentations and related to attracting the attention of learners were most apparent ones. While describing an effective PowerPoint presentation, the participants have mentioned that it should include visual representations, video links, graphics, animations, cartoons, tables and so forth to encourage students' engagement and to make them alert. In this regard, in a study conducted by Lazar (2017) regarding the effectiveness of audio visual aids, $80 \%$ of the entire students supported the idea that the animated PowerPoint presentations were very helpful to make them alert and very active in the class.

Since most of the participants were first time speakers, they interpreted their nervousness as an indicator of their incapability of delivering a good presentation. Although nervousness may easily lead to lack of confidence for beginners, no one in the audience will blame you for being a beginner or being inexperienced provided you do your best (Niemantsverdriet,2000).

Regarding the theme "Contributions of activities carried out during the ITMD course to the process", the codes boosting self-confidence and increasing motivation were most predominantly occurring ones. Based on the fact that the construct of selfconfidence influences efficacy expectations, the framework for the study situated the student at the center, without taking into account the teaching method selected, attempts to increase students' self-confidence positively contribute to both behavior and performance Chlan, Halcon, Kreitzer \& Leonard (2005). Ferguson (1996) believed that developing self-confidence would have a positive impact on the student's professional performance. However, it should be noted that confidence exists as a constant fluctuation depending on students' interpretations of experiences that increase perpetually with knowledge, experience and time (Hine, 2006). In a study conducted by Opacic (2003) practical performance was associated with the variables of self-efficacy and motivation. Students who were optimistic about their performance showed greater desire and motivation. All participants agreed that low-confidence limited or stopped learning.

Most participants stated that the ITMD course provided them with knowledge of different materials and their use in a friendly classroom atmosphere without hesitating to interact to each other. In this vein, Ingersoll and Strong (2011) have claimed that an effective teacher provides students with appropriate practice or exercise in a real situation, creates a teaching atmosphere that allows students to think and discuss, guides students to think by using questioning skills, sets reasonable classroom rules and incentive provisions and, properly handles student misconduct or unexpected conditions. From the views of the participants, it is apparent that all these requirements are met in the ITMD course by the students and the instructor mutually.

\section{Conclusion}

This study attempted to evaluate the development and presentation process of materials prepared by sophomores within the scope of ITMD course in accordance with the views of sophomore preservice primary teachers who take ITMD course. Students expressed their views in line with the themes generated according to the scope of the process. The participants expressed their opinions on choosing a topic, preparing a lesson plan related to the topic they have chosen, preparing a material 
related to the topic they have chosen and preparing a presentation related to the topic they have chosen. The views revealed that students have positive opinions about the development and presentation process of materials. However, regarding preparing a material and preparing a presentation themes, the participants also mentioned some difficulties they experienced during this process.

On the other hand, in the light of these findings in spite of being obtained from a relatively small sample, the ITMD course provided the basic ideas of preparation and use of materials essential to the understandings of the expected performances. To meet high expectations from students, it is suggested that teachers gain experience in using materials through their own efforts and in-service training programs. Since, the ITMD course enables technology to be used in teaching situations and requires the teacher to be sufficiently equipped with the knowledge of technology, teacher training programs should meet technological knowledge requirements of teachers both theoretically and practically in order to train technologically competent teachers. It is also suggested that at the end of the term, the prepared materials by students be exhibited in the faculty or any other exhibition hall in the university for other teachers and students to visit and see them. Another suggestion includes sharing the materials prepared by the students within the scope of the ITMD course with nearby schools or village schools so that they make use of them in their teaching- learning process.

While the present study may provide some insights about material development and presentation process of primary preservice teachers, the generalizability of the findings is limited, due to its small sample size. Therefore, more extensive research with a larger sample size is suggested for future researchers. Another limitation of the study was that the topic, the evaluation of Instructional Technologies and Material Design Course, has been studied commonly. Therefore, this study concentrated on material development and presentation process within the ITMD context rather than discussing the scope of the entire course. Further research could concentrate on an in depth study on what it would require to increase the use of technology in the ITMD course.

\section{References}

Akçay, H., Tüysüz, C., Feyzioğlu, B., \& Oğuz, B. (2008). Bilgisayar tabanlı ve bilgisayar destekli kimya öğretiminin öğrenci tutum ve başarısına etkisi. Mersin Üniversitesi Eğitim Fakültesi Dergisi, 4(2), 169-181.

Barnard, R. \& Zemach, D. (2003). Materials for specific purposes. In Tomlinson, B. (ed). Developing Materials for Language Teaching, London: Continuum: 306-323.

Boyatzis RE (1998) Transforming qualitative information. Sage: Cleveland

Chlan, L., Halcón, L., Kreitzer, M., \& Leonard, B. (2005). Selected complementary therapy skills influence of an experiential education session on nursing students' confidence levels in performing. Complementary Health Practice Review, 10, 189-201 DOI: 10.1177/1533210105284044.

Cohen, J. (1960) A coefficient of agreement for nominal scales. Educational and Psychological Measurement, 20, 37-46.

D'Andrea, L., Waters, C. \& Rudd, R. (2011). Using computer assisted qualitative software (CAQDAS) to evaluate a novel teaching method for introductory statistics. International Journal of Technology in Teaching and Learning, 7(1), 48-60 
Demirel, Ö., Seferoğlu, S.S., Yağc1, E. (2004). Öğretim teknolojileri ve materyal geliştirme. Ankara: PegemA.

Ferguson, L. M. (1996). Preceptors enhance students' self-confidence. Nursing Connections, 9 (1), 49-61.

Georgina, D. A. \& Hosford, C. C. (2009). Higher education faculty perceptions on technology integration and training. Teaching and Teacher Education, 25, 690696

Hamza, M. (2012). Developing training material guide. Swedish Civil Contingencies Agency (MSB). Retrieved from https:/ / www.msb.se/RibData/Filer/pdf/26433.pdf

Heinich, R., Molenda, M., Russell, J. D. \& Smaldino, S. E. (2002). Instructional media and technologies for learning (7th Ed.). Merrill Prentice Hall, USA.

Hidi, S. (1990). Interest and its contribution as a mental resource for learning. Review of Educational Research, 60, 549-571

Hidi, S., \& Renninger, K. A. (2006). The four-phase model of interest development. Educational Psychologist, 41,111-127.

Hine, L.R. (2006). Development of student nurse self-confidence in clinical practice. Doctoral Dissertation. College of Graduate Studies University of Idaho, the USA. UMI Number: 3250635

Inal, K. (2005). Yeni ilköğretim müfredatının felsefesi. Muhafazakar Düşünce, 6, 75-92.

Ingersoll, R. M., \& Strong, M. (2011). The impact of induction and mentoring programs for beginning teachers: A critical review of the research. Review of Educational Research, 81(2), 191-201. DOI: 10.3102/0034654311403323

Khadjooi, K., Rostami, K., \& Ishaq, S. (2011). How to use Gagne's model of instructional design in teaching psychomotor skills. Gastroenterol Hepatol Bed Bench, 4(3), 116-119.

Lazar, E. (2017). Effectiveness of audio visual aids in English language learning. The Literary Herald Journal, 3 (3), 78-90.

Li, N. (2012). Approaches to learning: Literature review. International Baccalaureate Organization. Retrieved from

https://www.ibo.org/globalassets/publications/ibresearch/approachestolea rningeng.pdf

Link, A. N., Swann, C. A., \& Bozeman, B. (2008). A time allocation study of university faculty. Economics of Education Review, 27(4), 363-374.

Merriam, S. B. (1998). Qualitative research and case study applications in education. San Francisco: Jossey-Bass.

Metzger, M. J., Flanagin, A. J., Zwarun, L. (2003). College student Web use, perceptions of information credibility, and verification behavior. Computers $\mathcal{E}$ Education, 41, 271-290

Miles, M, B., \& Huberman, A. M. (1994). Qualitative data analysis: An expanded sourcebook. (2nd ed). Thousand Oaks, CA: Sage.

Ministry of National Education [MoNE]. (2004). Programların geliştirilmesini gerekli kılan nedenler. Retrieved from: http:/ / programlar.meb.gov.tr/prog_giris/prog_giris11.html

Moreno, R., \& Mayer, R. E. (2002). Verbal redundancy in multimedia learning: When reading helps listening. Journal of Educational Psychology, 94(1), 156-163. 
Niemantsverdriet, J.W. (2000). How to give successful oral and poster presentations. Schuit Institute of Catalysis, Eindhoven University of Technology Eindhoven, The Netherlands. Retrieved from https:/ / www.eng.auth.gr/ chemtech/foititika/various/niemantsverdriet_20 00_presentations_howto.pdf

Oblinger, D. (2005). Leading the Transition from Classrooms to Learning Spaces: The convergence of technology, pedagogy, and space can lead to exciting new models of campus interaction. Educase Quarterly, 1, 14-18

Opacic, D. A. (2003). The relationship between self-efficacy and student physician assistant clinical performance. Journal of Allied Health, 32 (3), 158-166.

Pang, M. (2016). Companion guides for lesson planning: a planning template and the lesson plan pro forma. ELT Journal, 7(4), 444-454. DOI: 10.1093/elt/ccw053

Rasul, S., Bukhsh,Q., Batoolc, S. (2011). A study to analyse the effectiveness of audiovisual aids in teaching learning process at university level. Procedia Social and Behavioural Sciences, 28 (1), 78 - 81.

Rice, P. L., \& Ezzy, D. (1999). Qualitative research methods: A health focus. South Melbourne (Australia): Oxford University Press.

Starman, A. B. (2013). The case study as a type of qualitative research. Journal of Contemporary Educational Studies/Sodobna Pedagogika, 64(1), 28-43.

Sheldon, K., \& Elliot, A. (1999). Goal striving, need satisfaction, and longitudinal well-being: The self-concordance model. Journal of Personality and Social Psychology, 76, 482-497.

Tutty, L.M., Rothery, M. S. \& Grinnell, R.M. (1996). Qualitative research for social workers: Phases, steps and tasks. London: Allyn \& Bacon

Yalın, H.İ. (2002). Öğretim teknolojileri ve materyal geliştirme. Ankara: Nobel Yayınları.

Yaşar, O. (2004, İlköğretim sosyal bilgiler derslerinde görsel materyal kullanımı ile coğrafya konularının eğitim ve öğretimi. Milli Ĕ̆itim Dergisi, 163.

Yıldırım, A., \& Şimşek, H. (2008). Sosyal bilimlerde nitel araştırma yöntemleri (6. Baskı). Ankara: Seçkin Yayıncılık

YÖK (1998). Ĕ̆itim fakültesi öğretmen yetiştirme lisans programları. Ankara: Y.Ö.K.

Zhou, Q., Zhao, Y., Hu, J., Liu, Y., \& Xing, L. (2010). Pre-service chemistry teachers' attitude toward ICT in Xian. Procedia Social and Behavioral Sciences, 9, 14071414 . 
Table 6

\section{Appendix}

Kappa Values of the Themes Generated from the Views of the Participants

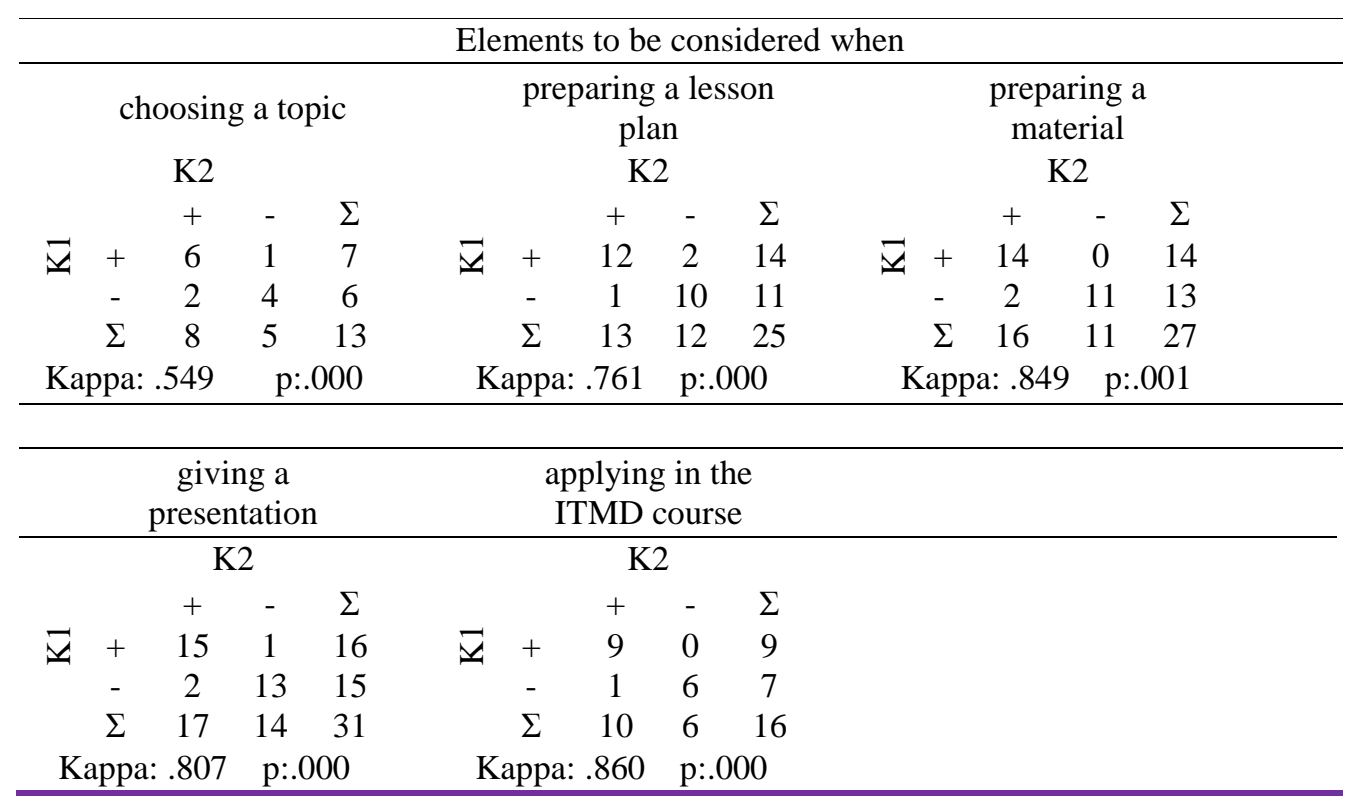

\section{Authors' Biodata/Yazar Bilgileri}

Şenel Elaldı is an associate professor in Education Faculty of Cumhuriyet University, Sivas, Turkey. She completed her doctoral degree at the Educational Sciences Institute of Frrat University, Turkey. Her research interests include curriculum and instruction studies.

Şenel ELALDI Cumhuriyet Üniversitesi Eğitim Fakültesi'nde docent olarak görev yapmaktadır. Doktorasını Fırat Üniversitesi Eğitim Bilimleri Enstitüsü'nde tamamlamıştır. İlgi duyduğu çalışma konuları eğitim programları ve öğretimdir. 